\title{
Ucides cordatus cordatus (Linnaeus, 1763) (Crustacea, Decapoda). Complete larval development under laboratory conditions and its systematic position. ${ }^{1}$
}

\author{
Misael Domingues Rodrigues ${ }^{2}$ \\ Nilton José Hebling ${ }^{3}$
}

\begin{abstract}
Six zoeal stages and the megalopa of the comestible crab Ucides cordatus cordatus (Linnaeus, 1763) are described and illustrated. The larvae were reared in the laboratory at temperature $25 \pm 1^{\circ} \mathrm{C}$ and water salinity of $240 / 00$; duration of stages and survival rates were measured. Comparisons with the descriptions of the zoeal morphologic characters of Ocypodidae and Gecarcinidae permited to include definitively $U$. c. cordatus in the family Ocypodidae, subfamily Ocypodinae.
\end{abstract}

\section{INTRODUCTION}

The comestible crab, Ucides cordatus cordatus, is very commom in the mangrove forests of the Western Atlantic coast, occurring, according to COELHO \& RAMOS (1972), from Florida, Antiles, northern South America, Guiana to Brazil (to the State of Santa Catarina).

Based upon the morphology of the adults, the genus Ucides Rathbun, 1897 has characteristics of both families Gecarcinidae and Ocypodidae. H. MILNE EDWARDS (1837), LEBOUR (1928), RATHBUN (1918, 1933), HOLTHUIS (1959), BRIGHT (1966) and PRAHL \& MANJARRÉS (1984) considered it in the family Gecarcinidae while CHACE \& HOBBS (1969), TURKAY (1970), WARNER (1977) and MELO (1985) in the family Ocypodidae.

In this paper are described and illustrated all the larval forms of U.c. cordatus. The larval characters are compared with those of the other species of Gecarcinidae and Ocypodidae in order to help solve the controversal systematic position of this genus.

\section{MATERIAL AND METHODS}

Ovigerous females of $U$. c. cordatus were collected on January 18,1981

Research supported by CAPES -PICD.

2 Departamento de Biologia Geral - Centro de Ciências Biológicas - UEL - Caixa Postal 6001 - 86051 Londrina-PR.

3 Departamento de Zoologia - Institu to de Biociências - UNESP - Campus de Rio Claro Caixa Postal 178 - 13500 Rio Claro, SP. 
in the mangroves in the canal of Bertioga $\left(23^{\circ} 51^{\mathrm{S}} \mathrm{S}, 46^{\circ} 09 \mathrm{~W}\right)$, northern litoral of São Paulo, Brazil.

After eclosion 60 zoeae were isolated in Petri dishes of $20 \mathrm{ml}$, with sea water having a salinity of $24 \%$ and maintained in a climatic room at $25 \pm 1{ }^{\circ} \mathrm{C}$ with a photoperiod of 12 hours light and dark. During all their development, the larvae were fed with freshly hatched nauplii of Artemia salina, after daily changes of water.

Dead larvae were fixed and preserved in a mixture of ethol alcohol $70 \%$ and glycerine in a proportion of 1:1. The exuviae were preserved in glycerine.

Measurements and designs were made using a Zeiss microscope with drawing tube. When possible 10 larvae of each stage were analyzed.

The following symbols were adopted for the diferent larval stages: I, first zoeal stage; II, second zoeal stage; III, third zoeal stage; IV, fourth zoeal stage; $\mathrm{V}$, fifth zoeal stage that produces zoea VI; $\mathrm{V}_{1}$, fifth zoeal stage that produces directly the megalopa; VI, six th zoeal stage; $M_{1}$, megalopa produced by zoea $\mathrm{V}_{1} ; \mathrm{M}_{2}$, megalopa produced by zoea VI.

The figures and morphological descriptions of the fifth zoeal stage and of the megalopa were based, respectively, upon stages $V$ and $M_{2}$, because they were most common in the larval development. For stages $V_{1}$ and $M_{1}$ only the alternate morphologies were mentioned in relation to $\mathrm{V}$ and $\mathrm{M}_{2}$.

\section{RESULTS}

Rearing Experiment. The larval development of U.c. cordatus is constituted by five or six stages of zoea and one of megalopa, the prezoea stage does not occur. Among the 45 obtained megalopae, 41 passed through 6 stages of zoea and 4 originated directly from zoea $V_{1}$.

The complete larval development resulting in the formation of the first juvenile stage accurred in 19 individuals: 2 from megalopa $M_{1}$ and 17 from $\mathrm{M}_{2}$. in Table I.

The duration and survival of the larval stages from eclosion are presented in Table 1.

TABLE I - Ucides cordatus cordatus (L.) - Cumulative duration and survival of larval stages in the salinity $24 \%$. I- $\mathrm{M}_{2}$, larval stages; $n$, initial zoeae number; D-D', mininimum and maximum duration of larval stages; $\overline{\mathrm{X}}$, stages duration mean (in days); $\mathrm{s}$, standard deviation; $\mathrm{s}_{\mathrm{x}}^{-}$, mean standard error; $\% \mathrm{~S}$, survival percentage. $\mathrm{n}=60$.

\begin{tabular}{ccrrrrrrrr} 
Stage & I & \multicolumn{1}{c}{ II } & III & IV & V & $\mathbf{V}_{1}$ & VI & $\mathbf{M}_{1}$ & \multicolumn{1}{c}{$\mathbf{M}_{2}$} \\
$\mathrm{D}-\mathrm{D}^{\circ}$ & \multicolumn{1}{c}{$6-9$} & $11-22$ & $15-29$ & $20-36$ & $24-34$ & $30-34$ & $28-52$ & $55-61$ & $43-69$ \\
$\overline{\mathrm{X}}$ & 6,77 & 12,92 & 19,07 & 23,97 & 29,22 & 31,75 & 36,51 & 58,00 & 57,76 \\
$\mathrm{~s}$ & 0,72 & 2,12 & 2,84 & 3,61 & 4,43 & 1,70 & 4,77 & 4,24 & 6,93 \\
$\mathrm{~S} \overline{\mathrm{X}}$ & 0,09 & 0,28 & 0,39 & 0,51 & 0,66 & 0,85 & 0,74 & 3,00 & 1,68 \\
\%S & 98,33 & 93,33 & 88,33 & 81,66 & 73,33 & 6,66 & 68,33 & 3,33 & 28,33
\end{tabular}




\section{DESCRIPTION OF THE LARVAE}

\section{ZOEA I}

CARAPACE (Fig. 1-I) - Smooth, globose with, frequently, 3 short simple setae posteroventrally. Dorsal spine equal in length to rostral spine, which is about twice length of antennae. Lateral spine absent in all stages. Eyes sessile.

ABDOMEN AND TELSON (Fig. 2-I) - With 5 segments; first naked, second and third with paired lateral knobs, fourth and fifth naked. Segments $2-5$ with short posterolateral spines overlapping adjacent segments and with a pair of short setae projecting from posterodorsal surface. Telson with shallow median notch. Inner arch of telson with $3+3$ processes having short setules.

ANTENNULE (Fig. 3-I) - Conical, uniramous, with 2 aesthetascs and 1 short simple seta.

ANTENNA (Fig. 4-I) - Biramous, with long, tapering protopodite armed with 2 rows of spinules. Exopodite with 2 unequal terminal setae.

MANDIBLE (Fig. 5-I) - Asymmetrically scoop-shaped, with dentate processes. Incisor process with $3-5$ teeth. Molar process irregularly dentate with 2 or 3 elevated cutting ridges.

MAXILLULE (Fig. 6-I) - Endopodite 2-segmented; proximal segment naked; distal segment with 2 terminal and 2 subterminal plumose setae. Basal and coxal endites with 5 and 4 processes respectively. Additional pubescense as illustrated.

MAXILLA (Fig. 7-I) - Endopodite with 2 terminal and 1 subterminal plumose setae. Basal endite with 4 plumose setae on distal lobe and 5 on proximal. Coxal endite with 3 plumose setae on both distal and proximal lobes. Scaphognathite with 4 plumose setae on outer margin, distal portion tapering to setose apical process. Additional pubescence as illustred.

FIRST MAXILLIPED (Fig. 8-I) - Coxopodite with 2 plumose setae. Basipodite with 9 plumose setae ventrally. Endopodite 5-segmented, with setation from base to tip of $2,2,1,2,5$. Exopodite 2 -segmented with 4 natatory plumose setae.

SECOND MAXILLIPED (Fig. 9-I) - Coxopodite with 1 plumose seta. Basipodite with 4 or 5 plumose setae ventraly. Endopodite 3-segmented with setation of $0,0,5$ from base to tip. Exopodite 2 -segmented with 4 natatory plumose setae.

\section{ZOEA II}

CARAPACE (Fig. 1-II) - Characters similar to first zoea, but eyes slightly stalked. 
Revta bras. Zool.

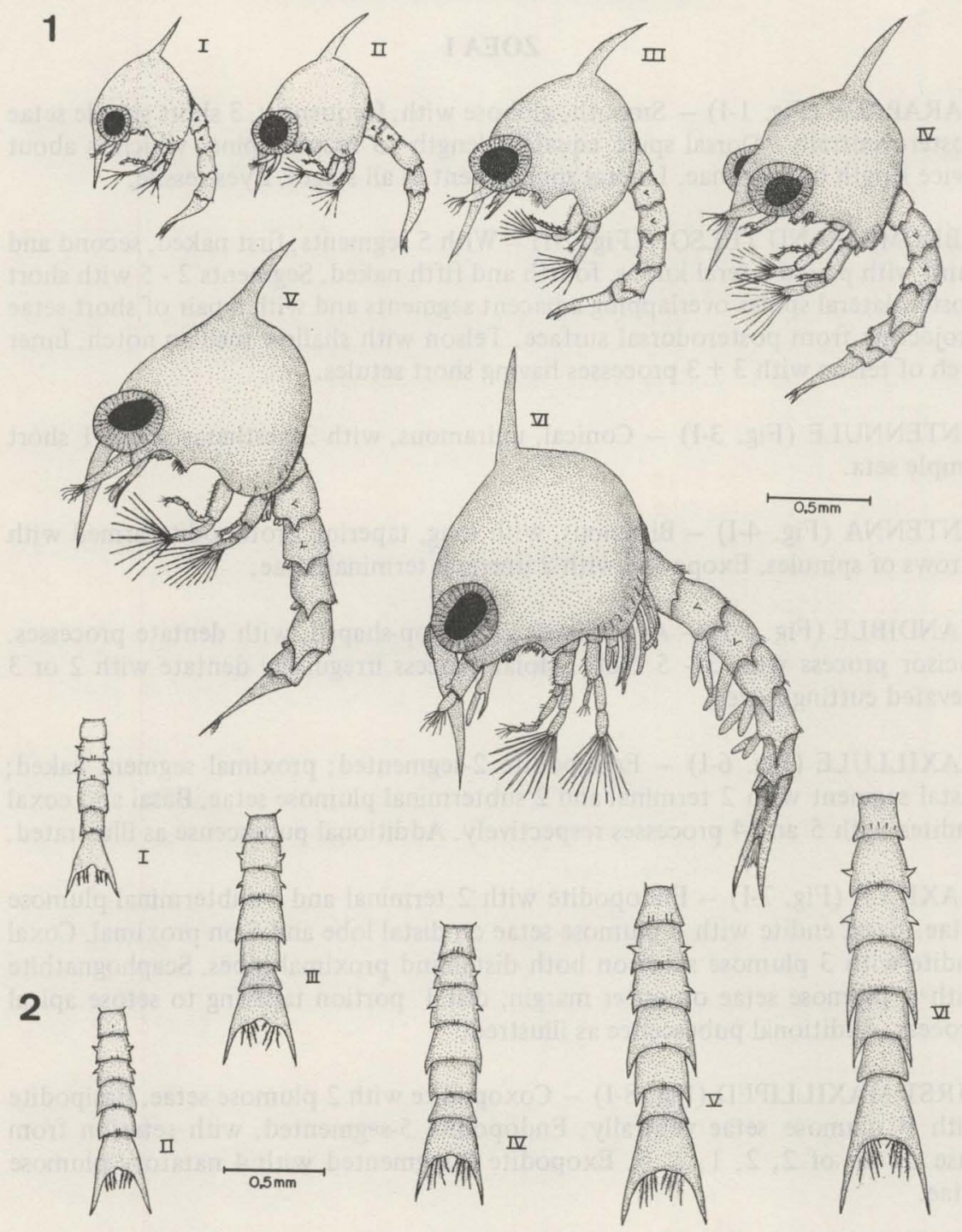

FIGS. 1-2: Ucides cordatus cordatus (L). 1, Lateral view, zoeal stages I - VI. 2 , Dorsal view, abdomen of zoeal stages I - VI.

ABDOMEN AND TELSON (Fig. 2-II) - Similar in shape and armature to first stage with addition of single short seta on posterodorsal surface of first abdominal segment. 
Vol. 6(1), 1989

ANTENNULE (Fig. 3-II) - Unchanged in form, now with 4 aesthetascs and 1 seta.

ANTENNA (Fig. 4-II) - Similar in form and armature to first stage.

MANDIBLE (Fig. 5-II) - Incisor process with 6 or 7 teeth.

MAXILLULE (Fig. 6-II) - Endopodite unchanged. Basal and coxal endites with 7 and 5 process respectively. Protopodite with 1 long plumose seta.

MAXILLA (Fig. 7-II) - Endopodite unchanged. Basal endite with 4 or 5 plumose setae on both distal and proximal lobes. Coxal endite with 3 or 4 plumose setae on both distal and proximal lobes. Scaphognathite with 5 plumose setae proximally and 3 on distal margin.

FIRST MAXILLIPED (Fig. 8-II) - Coxo - , basi - and endopodite setation unchanged. Exopodite with 6 natatory setae.

SECOND MAXILLIPED (Fig. 9-II) - Coxo- , basi- and endopodite setation unchanged. Exopodite with 6 natatory setae.

\section{ZOEA III}

CARAPACE (Fig. 1-III) - Characters similar to second zoea, but eyes stalked and 4 short simple setae, posteroventrally.

ABDOMEN AND TELSON (Fig. 2-III) - Sixth abdominal segment present. Inner arch of telson $4+4$ processes.

ANTENNULE (Fig. 3-III) - Unchanged.

ANTENNA (Fig. 4-III) - Unchanged.

MANDIBLE (Fig. 5-III) - Unchanged.

MAXILLULE (Fig. 6-III) - Endo-, protopodite and coxal endite unchanged. Basal endite with $8-10$ processes.

MAXILLA (Fig. 7-III) - Endopodite, basal and coxal endites unchanged. Scaphognathite with 7 or 8 plumose setae proximally and 4 on distal margin.

FIRST MAXILLIPED (Fig. 8-III) - Coxo-, basi- and endopodite setation unchanged. Exopodite with 8 natatory setae.

SECOND MAXILLIPED (Fig. 9-III) - Coxo, basi-and endopodite setation unchanged. Exopodite with 8 natatory setae. 

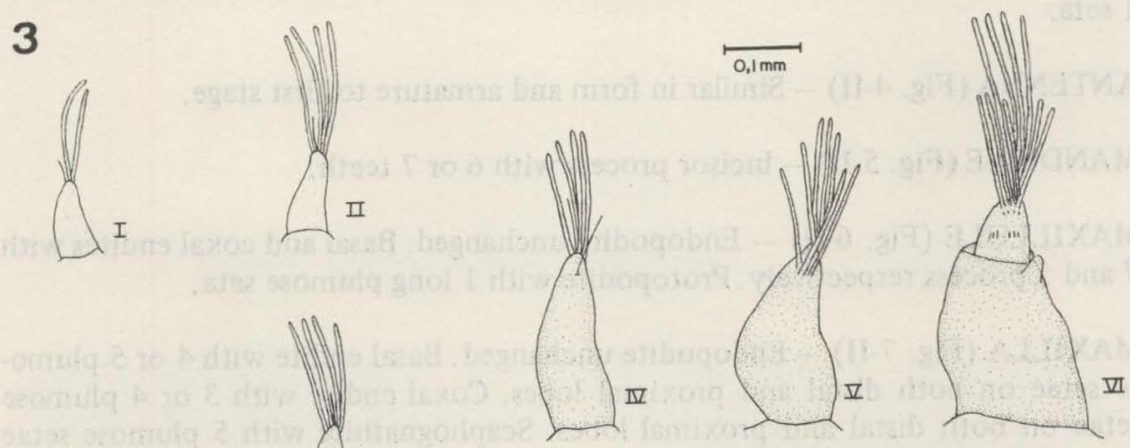

4
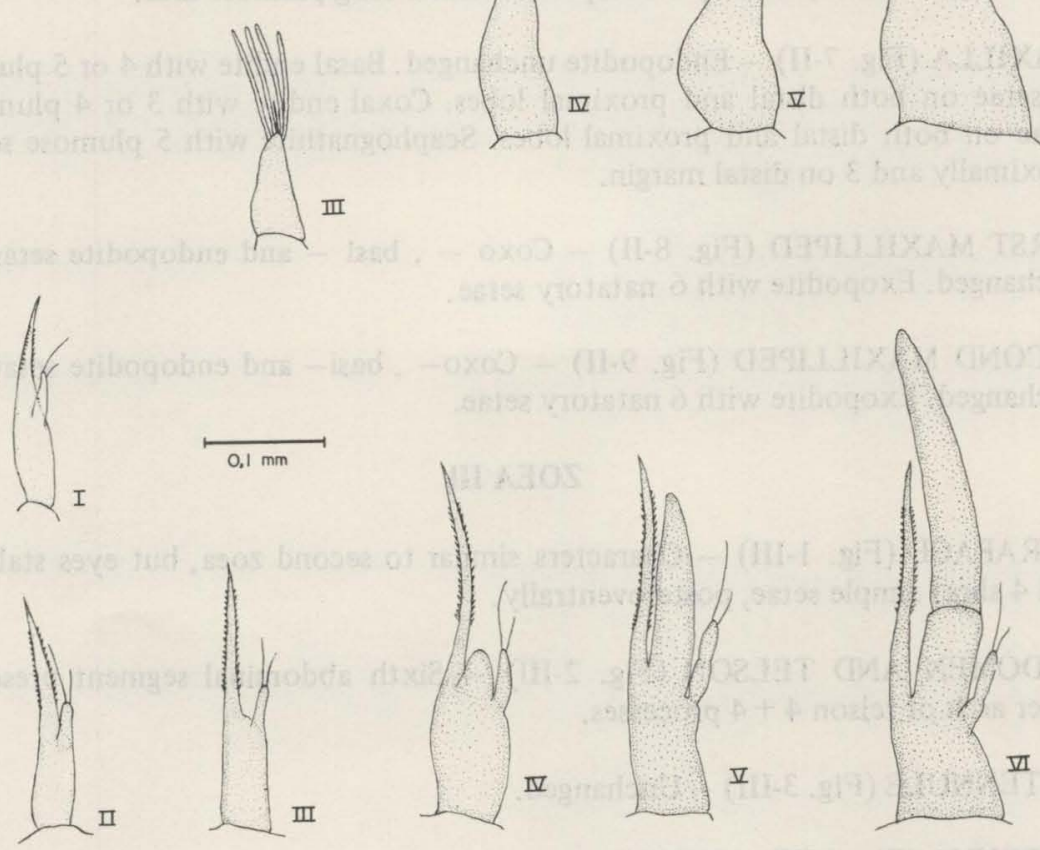

FIGS. 3-4: Ucides cordatus cordatus (L.). 3, Antennule of zoeal stages I - VI. 4, Antenna of zoeal stages I - VI.

\section{ZOEA IV}

CARAPACE (Fig. 1-IV) - Characters similar to third zoea. Rudimentary thoracic appendages appear.

ABDOMEN AND TELSON (Fig. 1-IV and 2-IV) - Similar to third zoea, but with 3 short setae on posterodorsal surface of first abdominal segment and with pleopod buds on the segments $2-5$.

ANTENNULE (Fig. 3-IV) - With 4 aesthetascs and 2 simple setae. 
ANTENNA (Fig. 4-IV) - Rudiment of endopodite present for first time.

MANDIBLE (Fig. 5-IV) - Unchanged.

MAXILLULE (Fig. 6-IV) - Endopodite unchanged. Basal endite with $8-10$ processes and $0-2$ simple setae. Coxal endite with $5-7$ processes and $0-2$ simple setae. Protopodite with 1 plumose and 1 simple seta.

MAXILLA (Fig. 7-IV) - Endopodite and basal endite unchanged. Coxal endite with 4 plumose setae on each lobe. Scaphognathite with $8-12$ plumose setae proximally and $4-6$ on distal margin.

FIRST MAXILLIPED (Fig. 8-IV) - Coxo- and basipodite unchanged. Endopodite with 2, 2, 1, 2, 6 setae. Exopodite with 9 natatory setae.

SECOND MAXILLIPED (Fig. 9-IV) - Coxo-, basi- and endopodite unchanged. Exopodite with 10 natatory setae.

THIRD MAXILLIPED (Fig. 9-IVa) - Present as small, nonfunctional bud.

\section{ZOEA V}

CARAPACE (Fig. 1-V) - Similar to previous stage but with $5-7(9-10$ in zoea $V_{1}$ ) short simple setae posteroventrally.

ABDOMEN AND TELSON (Fig. 1-V and 2-V) - With 4 (5 in zoea $\left.V_{1}\right)$ short setae on posterodorsal surface of first abdominal segment. Uropods present as buds on sixth abdominal segment.

ANTENNULE (Fig. 3-V) - With 4 terminal and $1-3$ subterminal aesthetascs $\left(\mathrm{V}_{1}\right.$ :2-segmented, with 4 terminal and $2-4$ subterminal aesthetascs and 0 or 1 simple seta on distal segment. Endopodite bud present or not).

ANTENNA (Fig. 4-V) - Endopodite equal or slightly shorter than spinous process. ( $\mathrm{V}_{1}$ similar to $\mathrm{V}$ or with a 2 -segmented endopodite extending beyond tip of protopodite).

MANDIBLE (Fig. 5-V) - Without palp ( $\mathrm{V}_{1}$ with a rudimentar palp).

MAXILLULE (Fig. 6-V) - Endopodite and basal endite unchanged. Coxal endite with $7-9$ processes and $0-2$ simple setae. Protopodite with 2 plumose setae. ( $\mathrm{V}_{1}$ :basal endite with 10 or 11 processes and $0-2$ simple setae).

MAXILLA (Fig. 7-V) - Endopodite unchanged. Basal endite with 5 plumose setae on distal lobe and 4 or 5 on proximal plus 0 or 1 simple setae in each one. Coxal endite with 4 or 5 plumose setae on distal lobe $4-6$ on proximal plus 1 or 2 simple setae on each one. Scaphognathite with $21-28$ marginal plumose 
5

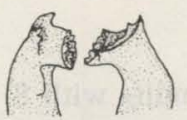

I

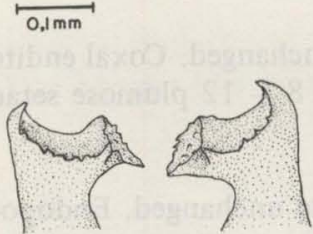

IV

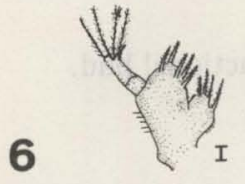

$0,1 \mathrm{~mm}$

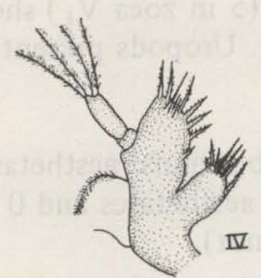

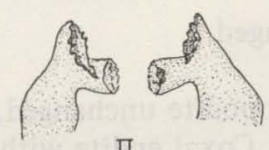

프

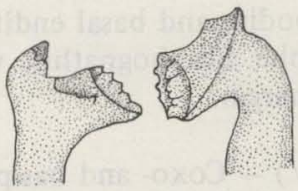

I
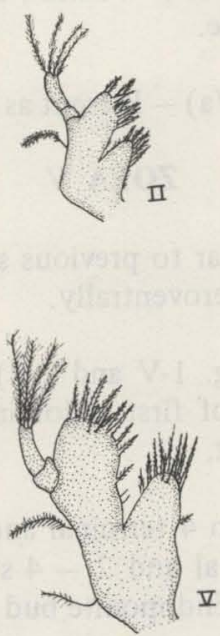

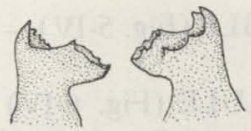

III

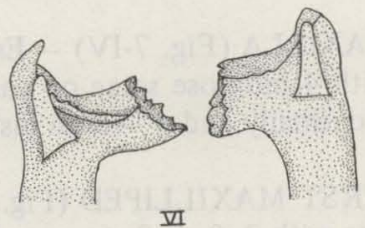

III
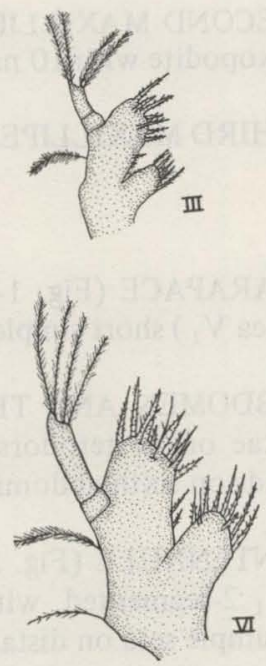

FIGS 5-6: Ucides cordatus cordatus (L.). 5, Mandible of zoeal stages I -VI. 6, Maxillule of zoeal stages I - VI.

setae or with 13 or 14 plumose setae proximally and 6 on distal margin. $\left(\mathrm{V}_{1}\right.$ : with a increase of 1 or 2 plumose setae on each lobe in both endites. Scaphognathite with $21-37$ marginal plumose setae).

FIRST MAXILLIPED (Fig. 8-V) - Coxo-, basi- and endopodite unchanged. Exopodite with 10 natatory setae $\left(\mathrm{V}_{1}\right.$ with 10 or 11$)$.

SECOND MAXILLIPED (Fig. 9-V) - Coxo- and endopodite unchanged. Basipodite with 4 or 5 plumose setae. Exopodite with 11 natatory setae $\left(V_{1}\right.$ with 12$)$. 
THIRD MAXILLIPED (Fig. 9-Va) - Rudimentary, 2-lobed, naked. $\left(\mathrm{V}_{1}\right.$ :both lobes more developed, one-half length of total appendage).

\section{ZOEA VI}

CARAPACE (Fig. 1-VI) - Similar to previous stage, but with $7-12$ short simple setae posteroventrally.

ABDOMEN AND TELSON (Fig. 1-VI and 2-VI) - With 5 - 7 short setae on posterodorsal surface of first abdominal segment. Pleopod and uropod buds elongate, all now with endopodites. Inner arch of telson now with $5+5$ processes, innermost pair the shortest.

ANTENNULE (Fig. 3-VI) - 2-segmented with a rudimentar endopodite. Exopodite with 4 or 5 terminal aesthetascs plus 0 or 1 simple seta and 4 or 5 subterminal aesthetascs. Additional pubescence as illustred.

ANTENNA (Fig. 4-VI) - Endopodite with 2 or 3 segments extending beyond tip of protopodite.

MANDIBLE (Fig. 5-VI) - With unsegmented palp.

MAXILLULE (Fig. 6-VI) - Endo- and protopodite unchanged. Basal endite with $10-14$ processes and 2 simple setae. Coxal endite with 9 or 10 processes.

MAXILLA (Fig. 7-VI) - Endopodite unchanged. Basal endite with 6 - 8 plumose setae on both lobes. Coxal endite with 4 or 6 plumose setae on distal lobe and 9 or 10 on proximal. Scaphognathite with $31-38$ marginal plumose setae.

FIRST MAXILLIPED (Fig. 8-VI) - Coxo-, basi- and endopodite unchanged. Exopodite with 10 or 11 natatory setae.

SECOND MAXILLIPED (Fig. 9-VI) - Coxo- and endopodite unchanged. Basipodite with 4 or 5 plumose setae. Exopodite with 11-13 natatory setae.

THIRD MAXILLIPED (Fig. 9-VIa) - Naked, with coxo- and basipodite. Exoand endopodite unsegmented.

\section{MEGALOPA}

CARAPACE (Fig. 10a) - With width $3 / 4$ of the length. Anterolateral lobe with 1 evident seta. Dorsal surface covered with very fine hairs. Ventral margin with numerous short plumose setae. Rostrum terminating as single median process, projected down wards.

ABDOMEN AND TELSON (Fig. 10a; $11 ; 13 \cdot \mathrm{Pl}_{2} \cdot \mathrm{Pl}_{5}, \mathrm{U}$ ) - Six segments, with short setae. Fifth segment with a posterolateral spine. Pleopods on abdominal 

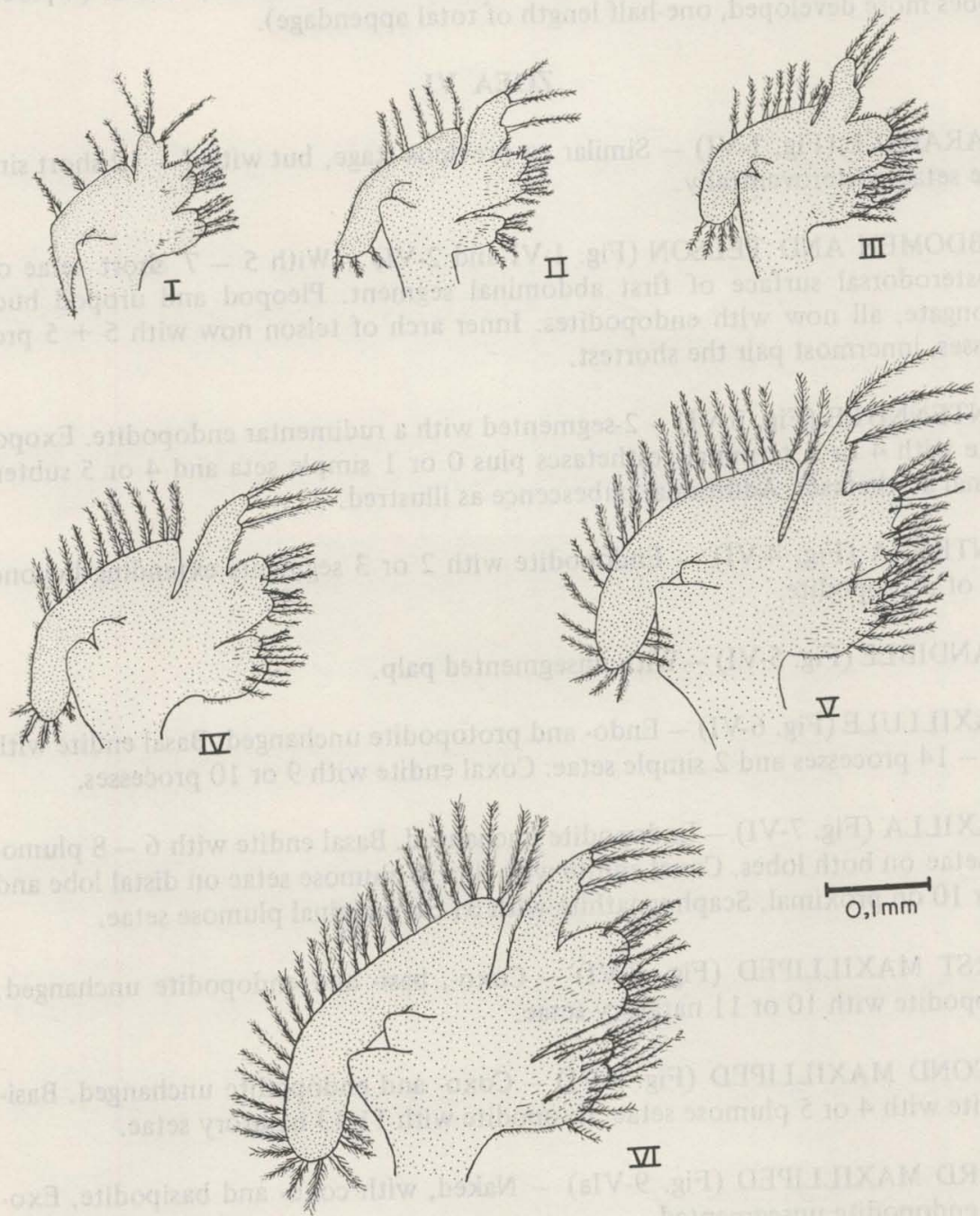

FIG. 7: Ucides cordatus cordatus (L.) - Maxilla of zoeal stages I -VI.

segments $2-5$, biramous, with variable setation: $18-20,17-20,17-20$, $16-18\left(M_{1}\right.$ with $\left.9-13,13-15,10-13,10-12\right)$ plumose setae on exopods, respectively and with $3\left(\mathrm{M}_{1}\right.$ with 1$)$ small hooked spines on each endopod. Uropods with $10-12\left(M_{1}\right.$ with 9$)$ exopodal plus 1 protopodal setae. Telson semicircular with marginal setae as ilustrated. Most (76\%) megalopae had telson as shown in Fig. $11: a(33 \%) ; b(24 \%) ; c(19 \%)$. 
Vol. $6(1), 1989$

ANTENNULE (Fig. 12a) - With 3-segmented peduncle and 2 flagella. Basal segment of peduncle inflated and bulbous with $3\left(\mathrm{M}_{1}\right.$ with 2$)$ plumose setae and 3 or 4 short simple setae; second segment with $4-7$ simple setae; third segment naked. Flagellar lower ramus unsegmented with 2 terminal simple setae; upper ramus 4 -segmented, with: 0,4 or 5,4 or 5,4 or 5 aesthetascs plus 1 or 2 simple setae on third and fourth segments or 5-segmented with $0,4,3$ or 4,3 or 4,3 or 4 aesthetascs plus 1 simple seta on fourth and 2 on fifth segments $\left(M_{1}\right.$ :upper ramus 3 -segmented, with $0,4,4$ aesthetascs plus 0,0 or 1,2 simple setae).

ANTENNA (Fig. 12b) - Peduncle 3-segmented with 3, 2, 2 setae $\left(M_{1}\right.$ with 2, 1 , $1)$; flagellum 7 or 8 -segmented $(87 \%)$ with setation $0,0,3,2,4,0,3,3\left(M_{1} 5\right.$ segmented with $0,0,3$ or $4,1,2$ or 3 ).

MANDIBLE (Fig. 12c) - Incisor process smooth, spatulate; palp 2-segmented with 5 or 6 simple setae plus 3 plumose setae on terminal segment $\left(M_{1}\right.$ with 4 simple setae).

MAXILLULE (Fig. 12d) - Endopodite 2-segmented with 4 or 5 simple setae on terminal segment. Basal endite with $12-15$ processes and 5 or 6 simple setae. Coxal endite with 13 or 14 processes and 6 or 7 simple setae. Protopodite with 6 plumose setae ( $\mathbf{M}_{1}$ with 2 marginal plumose setae).

MAXILLA (Fig. 12e) - Endopodite unsegmented with 2 terminal, 1 subterminal and 3 basal plumose setae. Basal endite with about 11 setae on distal lobe and 12 on proximal. Coxal endite with $15-17$ mid-basal setae; 3 or 4 setae on distal lobe and 5 on proximal. Scaphognathite with about 70 marginal plumose setae plus 4 on the blade as shown. $\left(\mathrm{M}_{1}\right.$ :basal endite with $5-8$ setae on distal lobe and $8-10$ on proximal; coxal endite with $12-16$ mid-basal setae beyond 1 seta on distal lobe and $2-4$ on proximal. Scaphognathite with about 50 marginal setae plus 3 on the blade).

FIRST MAXILLIPED (Fig. 13a) - Endopodite unsegmented with 6 plumose setae. Coxal and basal endites with about 12 and 14 simple setae respectively $\left(\mathrm{M}_{1}\right.$ with 6-8 setae on every one). Exopodite 2-segmented with 3 or 4 plumose setae on both proximal and distal segments. Epipodite with 10 simple setae ( $M_{1}$ with 3).

SECOND MAXILLIPED (Fig. 13b) - Endopodite 3-segmented with 2 simple setae on first segment, 4-6 plumose setae on second and 9 or 10 plumose setae plus 3 simple setae on third $\left(M_{1}: 3\right.$ or 4 simple setae on second segment and 4 plumose setae plus 2 simple setae on third). Exopodite 2 -segmented with 3 simple setae on first segment and 4-6 plumose setae on second.

THIRD MAXILLIPED (Fig. 13c) - Protopodite with 9-12 plumose setae $\left(\mathrm{M}_{1}\right.$ with 3). Endopodite 5-segmented with $10-13,7$ or $8,5-7.7$ or 8,8 or 9 setae progressing distally ( $M_{1}$ with 6,3 or $4,4,5,8$ setae). Exopodite 2-segmented with 3 simple setae on first segment and 4 plumose setae on second. Epipodite 
Revta bras. Zool.
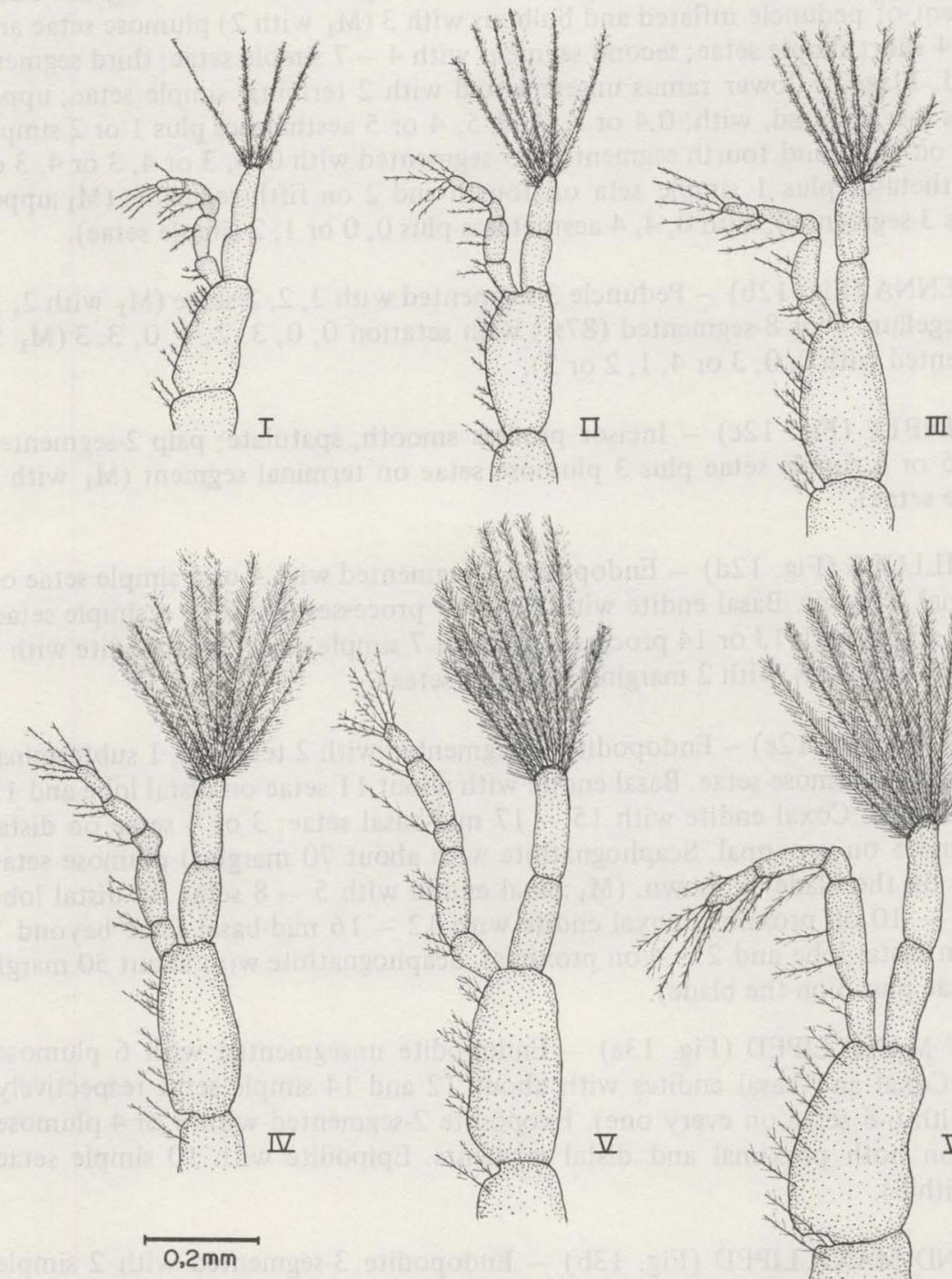

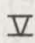

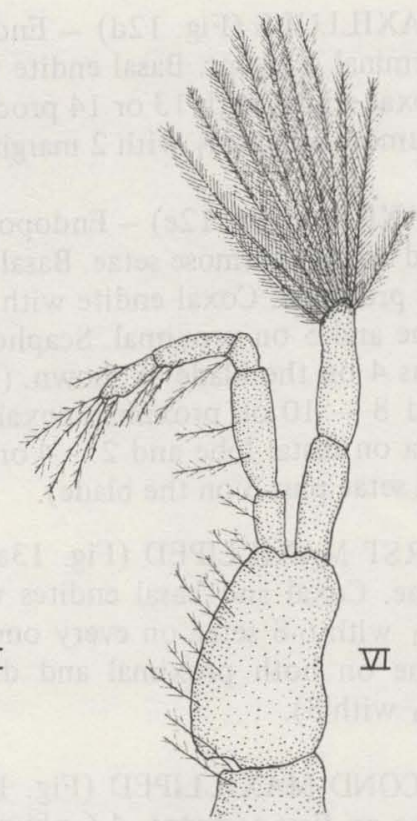

FIG. 8: Ucides cordatus cordatus (L.) - First maxilliped of zoeal stages I - VI.

with 7-10 basal plumose setae and 22 long simple setae $\left(M_{1}\right.$ with 3-5 mid-basal plumose setae and 5-7 long simple setae distally). 

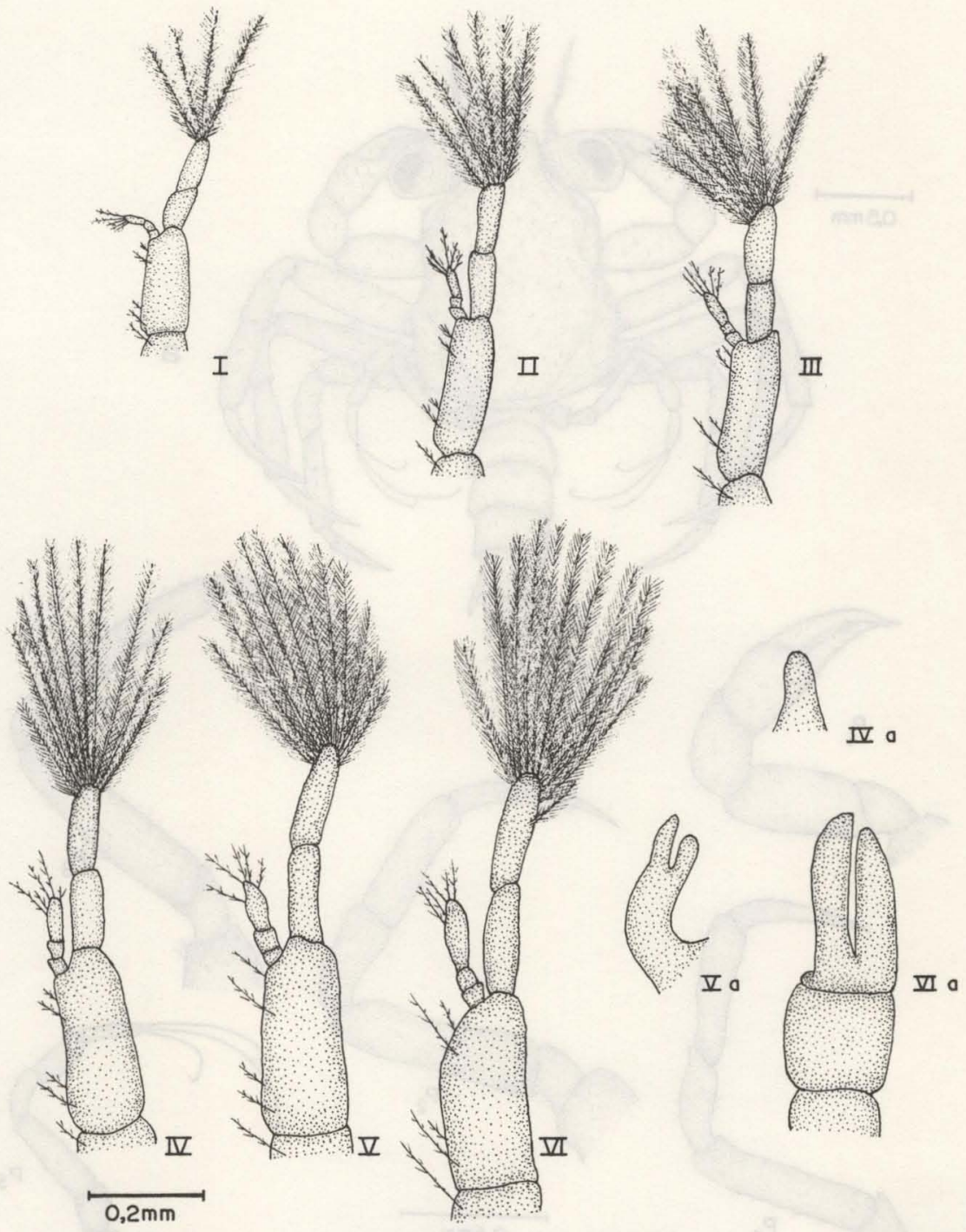

FIG. 9: Ucides cordatus cordatus (L.) -Second maxilliped of zoeal stages I-VI;VIa-VIa, third maxilliped of zoeal stages IV -VI.

PEREOPODS (Fig. 10a, $\mathbf{P}_{1}-\mathbf{P}_{5}$ ) - General setation as ilustrated. Chelipeds equal, relatively inflated, strongly gaping, cuting edge of both fingers smooth. Second to forth pereopods elongate, similar. Fifth pereopod dactyl with 3 long simple setae. 
Revta bras. Zool.

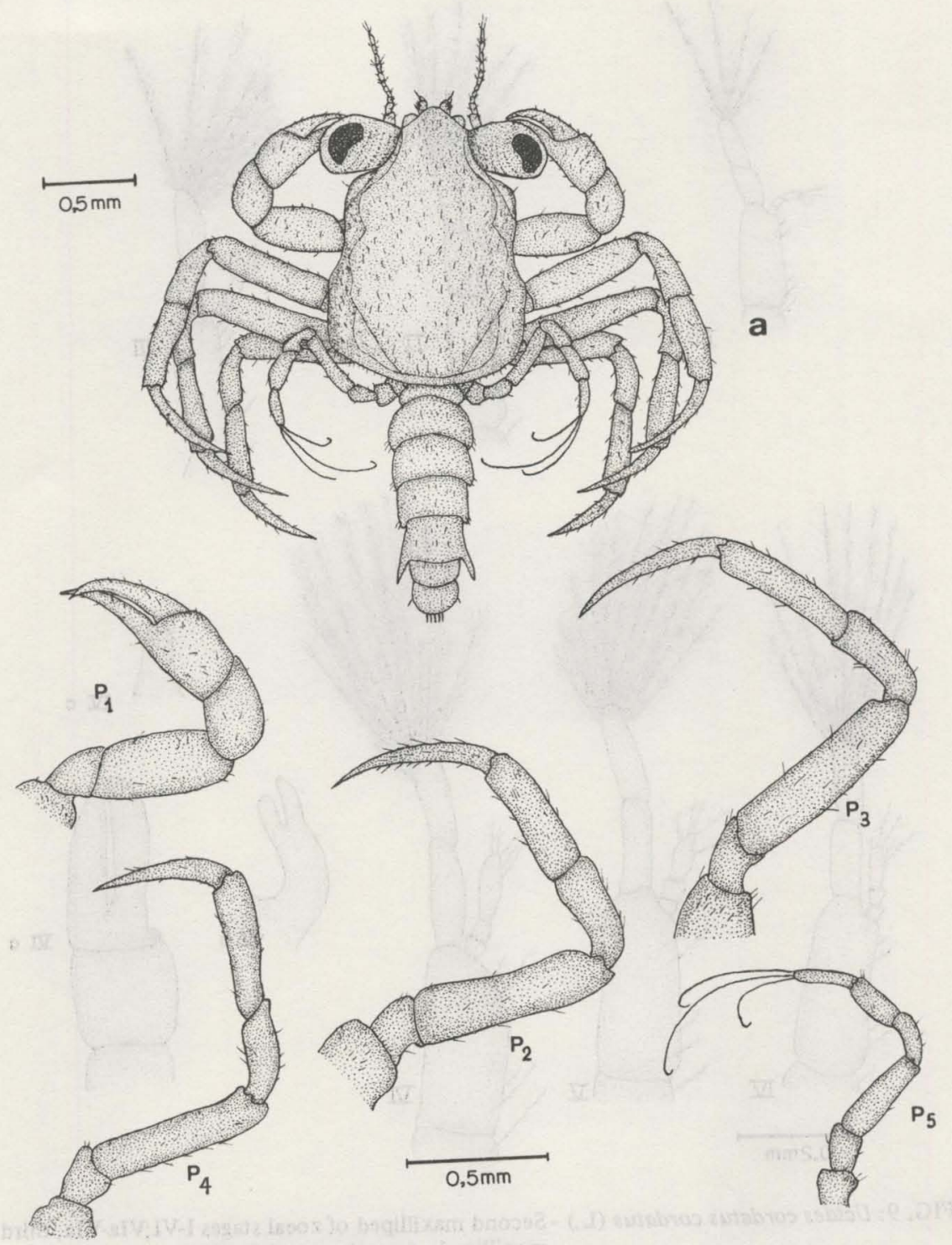

FIG. 10: Ucides cordatus cordatus (L.) - Megalopa. a, dorsal view; $\mathrm{P}_{1}-\mathrm{P}_{5}$, pereopods. 
Vol. 6(1), 1989
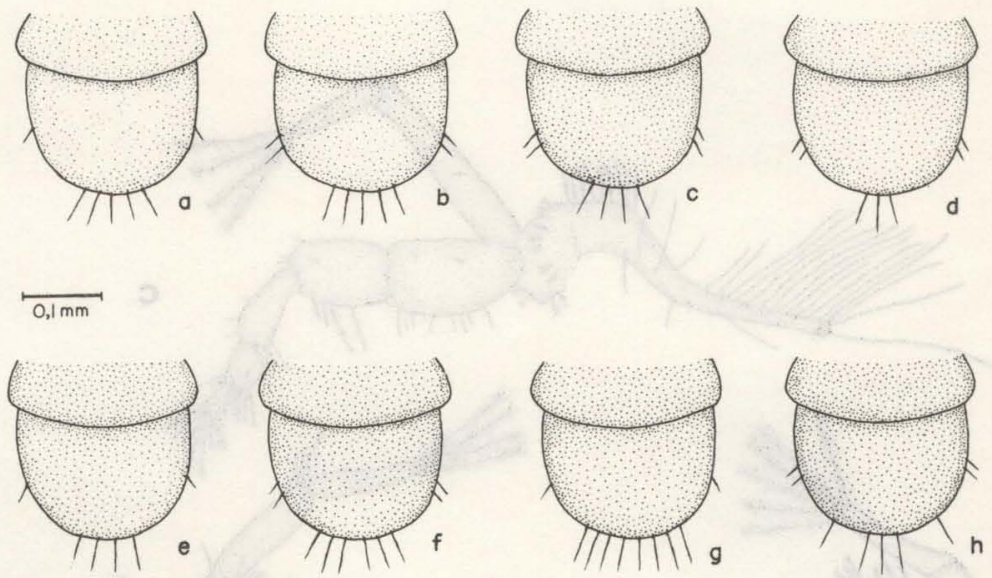

11

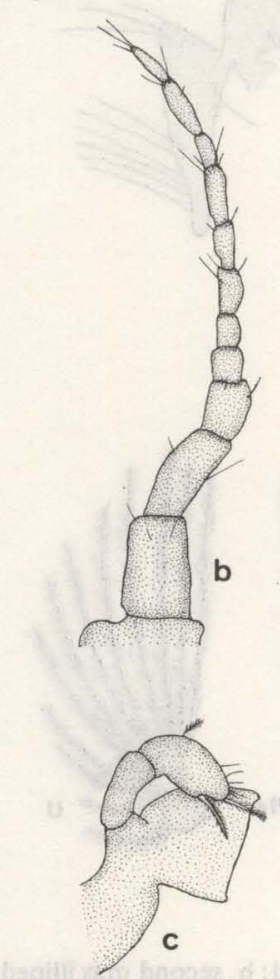

12

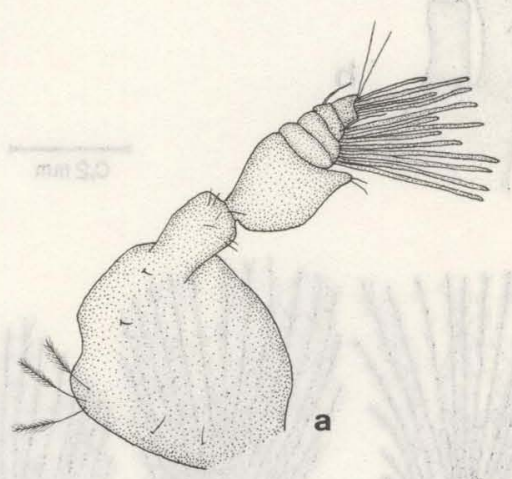

FIG. 11: Ucides cordatus cordatus (L.) - Megalopa. a - h, marginal setation of the telson. FIG. 12: Ucides cordatus cordatus (L.) - Megalopa. a, antennule; b, antenna; c, mandible; d, maxillule; e, maxilla. 
Revta bras. Zool.
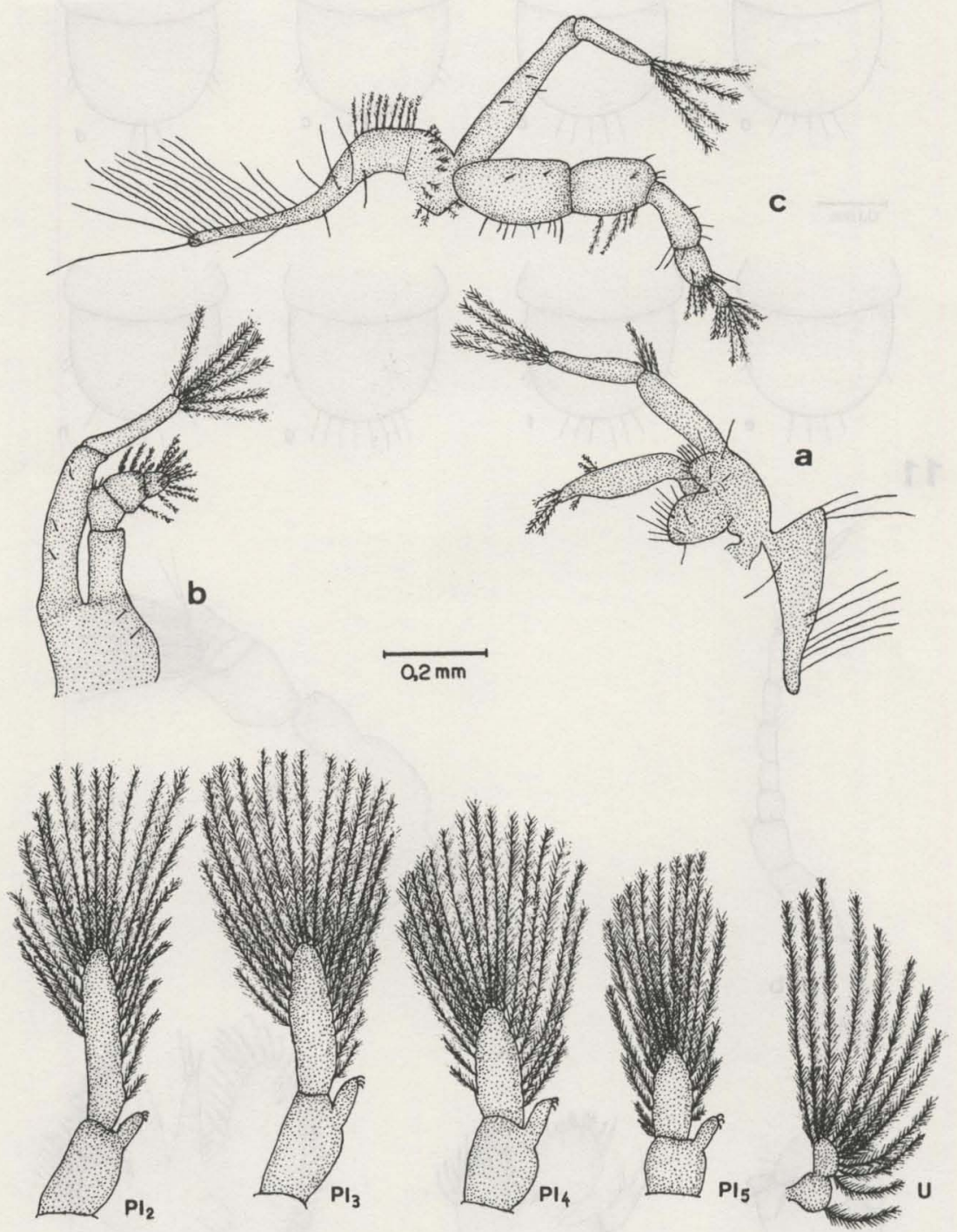

FIG. 13: Ucides cordatus cordatus (L.) - Megalopa. a, first maxilliped; b, second maxilliped; c, third maxilliped; $\mathrm{Pl}_{2}-\mathrm{Pl}_{5}$, pleopods; $\mathrm{U}$, uropod. 


\section{DISCUSSION AND CONCLUSION}

In analysis of characters of zoeae of the Ocypodidae, TERADA (1979) proposed the separation of species into three groups according to the number of setae on the endopodite of the maxillule and maxilla. In the first group, represented by the genera $U c a$ and Ocypode, the number of setae is $0-4$ and $1+2$; in the second group, which includes Macrophthalmus, it is $1-1+4$ and $2+2$; in the third group, represented by Dotilla, Scopimera, Ilyoplax, and Paracleistostoma, it is $0-4$ and $2+3$. These groups, according to the same author, correspod, respectively, to the subfamilies Ocypodinae, Macrophthalminae and Scopimerinae ( = Dotillinae Stimpson, 1858 according to MANNING and HOLTHUIS (1981)). RICE (1980), in an extensive work on the morphology of zoeae of Brachyura, accepted, in general, the same groupings proposed by Terada (op. cit).

A comparative analysis of the characters of zoeae of Ucides cordatus cordatus with those species included in the families Ocypodidae and Gecarcinidae with larval development totally or partially known, is presented in the TABLE II.

Based upon characters for comparison (spines on the carapace and arrangement of setae on the endopodite of the maxillule, maxilla and second maxilliped) it is confirmed that $U$. c. cordatus is not related to the Gecarcinidae and must definitively be included in the family Ocypodidae, particularly in the subfamily Ocypodinae, the only one that occurs in Brazil. Also, it is verified that there is a close similarity between the characters of the zoeae of $U$. $c$. cordatus and those of other species of the genus Uca.

FIELDER and GREENWOOD (1985a, 1986), using other characters presented by zoeae affirmed that Heloecius cordiformis should be included in a new subfamily (Heloeciinae Turkay, 1983) and suggested that the taxonomic status of Macrophthalmus hirtipes must be investigated in more detail.

Based upon morphology of the adults, GUINOT (1979) and MANNING and HOLTHUIS (1981) considered yet another new subfamily (Camptandriinae) in the Ocypodidae where Paracheistostoma cristatum would be allocated together with various species of other genera. From the larval view point, the validity of this new proposal can only be confirmed with the study of zoeae of the many species included in this subfamily.

Even though, in the present study, the morphology of the megalopa of $U$. c. cordatus is described in detail, it was impossible to conduct a comparative study with other species of the Ocypodidae and Gecarcinidae because, although known from a few specimens, most have only been partially described and/or figured. 
Revta bras. Zool.

TABLE II - Comparison of the zoeal characters of Ocypodidae and Gercarcinidae species with that Ucides cordatus cordatus (Linnaeus).

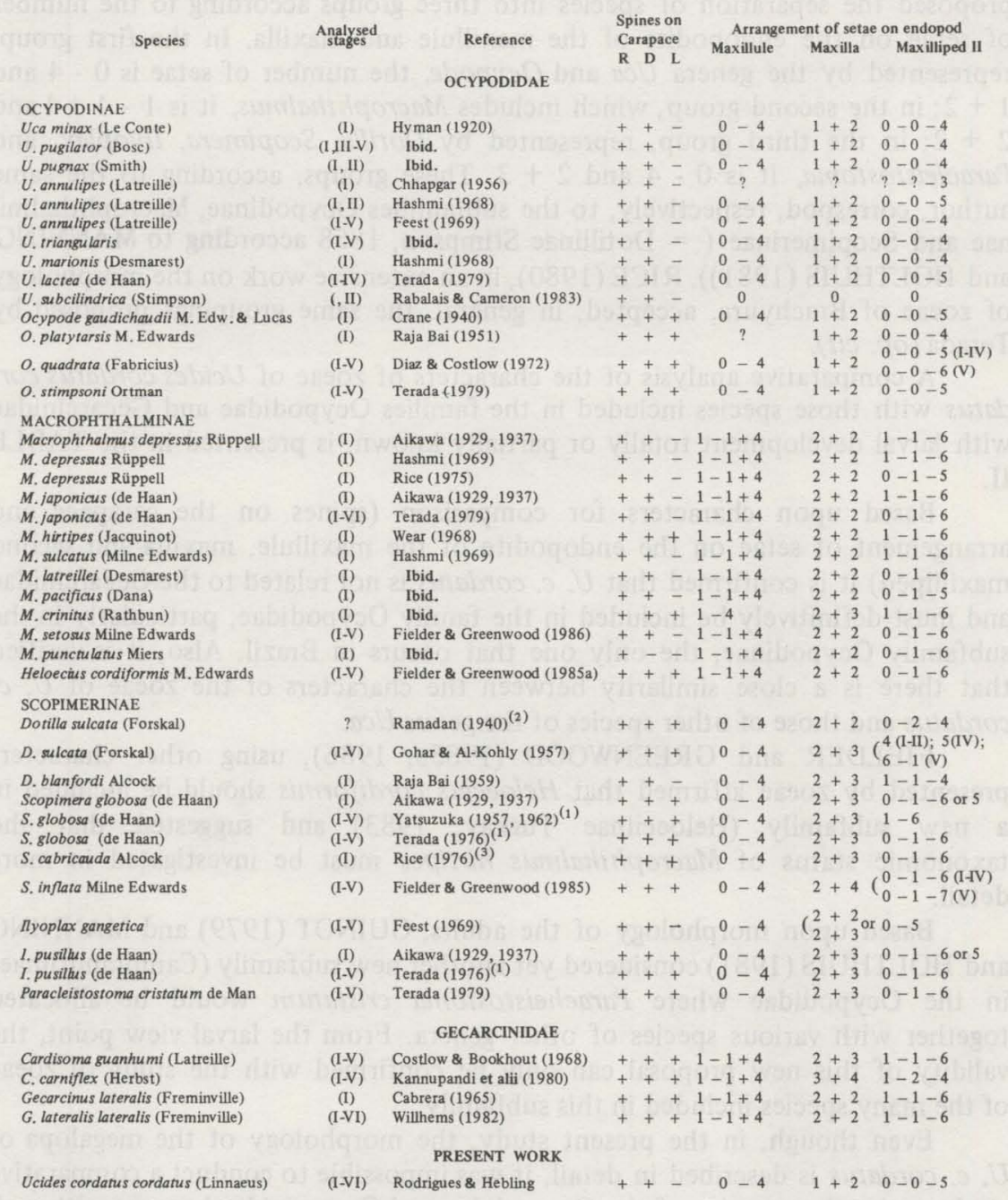

ABBREVIATIONS: R, rostral spine; D, dorsal spine; L, lateral spines; + present; - absent; ? no information; (I-VI), zoeal stages; $\left({ }^{1}\right),\left({ }^{2}\right)$, $\left({ }^{3}\right)$, apud TERADA, 1979; RICE, 1975; FIELDER \& GREENWOOD, 1985 respectively. 


\section{REFERENCES}

AIKAWA, H. 1929. On larval forms of some Brachyura. Rec. Oceanogr. Works Japan. 2:17$55^{\circ}$

AIKAWA, H. 1937. Further notes on brachyuran larvae. Rec. Oceanogr. Works Japan. 9: $87-162$.

BRIGHT, D. B. 1966. The land crabs of Costa Rica. Rev. Biol. Trop. 14(2):183-203.

CABRERA JR. J. A., 1965. Contribuiciones Carcinológicas. I. El primer estádio zoea en Gecarcinus lateralis (Fremnville) (Brachyura Gecarcinidae) procedente de Veracruz, Mexico. An. Inst. Biol. Mex. 36:173-187.

CHACE JR. F. A., \& H. H. HOBBS, 1969. The freshwater and terrestrial decapod crustaceans of the West Indian with special reference to Dominica. Bull. U. S. natl. Mus. 292:1-258.

CHHAPGAR, B. F. 1956. On the breeding habits and larval stages of some crabs of Bombay. Rec. Ind. Mus. 54:33-52.

COELHO, P. A. \& M. A. RAMOS. 1972. A constituição e a distribuição da fauna de decápodos do litoral leste da América do Sul, entre as latitudes $5^{\circ} \mathrm{N}$ e $39^{\circ} \mathrm{S}$. Trab. Oceanogr. Univ. Fed. Ped., Recife, 13:133-236.

COSTLOW Jr. J. D. \& C. G. BOOKHOUT. 1968. The complete larval development of the land-crab, Cardisoma guanhumi Latreille in the laboratory (Brachyura, Gecarcinidae). Crustaceana, Leiden. (Suppl. 2):259-270.

CRANE, J. 1940. Eastern Pacific Expeditions of the New York Zoological Society. XVIII. On the post-embryonic development of brachyuran crabs of the genus Ocypode. Zoologica. 25(1):65-82.

DIAZ, H. \& J. D. COSTLOW. 1972. Larval development of Ocypode quadrata (Brachyura: Crustacea) under laboratory conditions. Mar. Biol. 15:120-131.

FEEST, J. 1969. Morphophysiological studies on the ontogeny and sexual biology of Uca annulipes and Uca triangularis as compared to Ilyoplaz gangetica. Form. Funct. 1:159-225.

FIELDER, D. R. \& J. G. GREENWOOD, 1985. The complete larval development of the sand bubbler crab, Scopimera inflata H. Milne Edwards, 1837 (Decapoda, Ocypodidae), reared in the laboratory. Crustaceana, Leiden , 48(2):133-146.

FIELDER, D. R. \& J. G. GREENWOOD, 1985a. The systematic position of Heloecius cordiformis (H. Milne Edwards, 1837) (Decapoda, Ocypodidae) as revealed by larval morphology. Crustaceana, Leiden. 48(3):244-248.

FIELDER, D. R. \& J. G. GREENWOOD, 1986. Zoeal larvae of Macrophthalmus setosus H. Milne Edwards, 1852 and M. punctulatus Miers, 1884 (Decapoda, Ocypodidae). Mem.Qd. Mus. 22(2):155-164.

GOHAR, H. A. F. \& A. A. AL-KHOLY, 1957. The larvae of some brachyuran Crustacea (from the Red Sea). Publ. Mar. Biol. Sta. Al Ghardaga, Egypt. 9:145-176.

GUINOT, D. 1979. Données nouvelles sur morphologie, la phylogenèse et la toxonomie des crustacés décapodes brachyoures. Mém. Mus. natn. Hist. nat., Paris, sér. A. Zool. 112:3-354.

HASHMI, S. S. 1968. Stu dy on larvae of (Gelasimus) (Ocypodidae) reared in the laboratory (Decapoda: Crustacea). Pakist. J. Sci. Res. 20(1/2):50-56.

HASHMI, S. S. 1969. Studies on larval Ocypodidae (Macrophthalmus) hatched in the laboratory (Decapoda: Crustacea). Pakist. J. Sci. Res. 21 (1/2):42-54.

HOLTHUIS, L. B. 1959. The Crustacea Decapoda Of Suriname (Dutch Guiana). Zool.

Verh. Rijksmus. Nat. Hist. Leiden. 44:1-296.

HYMAN, O. W. 1920. On the development of Gelasimus after hatching. J. Morphol. 33 (2) :485-524.

KANNUPANDI, T.; S. A. KAN; M. THOMAS; S.SUNDARAMOORTHY, \& R. NATARAJAN, 1980. Larvae of the land crab Cardisoma carniflex (Herbst) (Brachyura: Gecarcinidae) reared in the laboratory. Ind. J. Mar. Sci. 9:271-277.

LEBOUR, M. V. 1928. The larval crabs of the Plymounth Brachyura. Proc. Zool. Soc. London. 473-560. 
MANNING, R. B. \& L. B. HOLTHUIS, 1987. West african brachyuran crabs (Crustacea: Decapoda). Smithson. Cont. Zool., Washington, 306:1-379.

MELO, G. A. S. de. 1985. Taxonomia e padröes distribucionais e ecologicos dos Brachyura (Crustacea: Decapoda) do litoral sudeste do Brasil. 215 pp. Tese de doutorado - USP São Paulo.

MILNE EDWARDS, H. 1837. Histoire Naturelle des Crustacés Comprenant l'Anatomie, la Physiologie et la Classification des ces Animaux. Librairie Encyclopédique de Roret, Paris, Vol. II, 532 pp.

PRAHL, H. von \& G. MANJARRES. 1984. Cangrejos Gecarcinidos (Crustacea: Gecarcinidae) de Colombia. Caldasia. 14:(66):149-168.

RABALAIS, N. N. \& J. N. CAMERON, 1983. Abbreviated development of Uca subcylindrica (Stimpson, 1859) (Crustacea, Decapoda, Ocypodidae) reared in the laboratory. J. Crust. Biol. 3(4):519-541.

RAJA BAI NAIBU, K. G. 1951. Some stages in the development and bionomics of Ocypoda platytarsis. Proc. Ind. Acad. Sci. 33(1):32-40.

RAJA BAI NAIDU, K. G. 1959. Studies on the larval development of Brachyura. I. The early and post-larval development of Dotilla blanfordi Alcock. Ann. Mag. Nat. Hist. (13) 2:129-135.

RATHBUN, M. J. 1918. The grapsoid crabs of America. Bull. U. S. natl. Mus. 97:1-461.

RATHBUN, M. J. 1933. Brachyuran crabs of Porto Rico and the Virgin Islands. Sci. Surv. Porto Rico and Virgin Islands, New York Acad.Aci., New York, 15(2):1-121.

RICE, A. L. 1975. The first zoeal stages of Cancer pagurus L., Pinnotheres pisum (Pennant) and Macrophthalmus depressus Rüppel (Crustacea, Decapoda, Brachyura). Bull. Br. Mus. nat. Hist. (Zool.) 28(5):237-247.

RICE, A. L. 1980. Crab zoeal morphology and its bearing on the classification of the Brachyura. Trans. Zool. Soc. Lond. 35:271-424.

TERADA, M. 1979. On the zoea larvae of five crabs of the family Ocypodidae. Zool. Mag. (Tokyo), 88(1):57-72.

TURKAY, M. 1970. Die Gecarcinidae Amerikas mit einem anhang über Ucides Rathbun. Senckenb. Biol. 51(5/6):333-354.

WARNER, G. F. 1977. The Biology of Crabs. Elek Science, London. 202 pp.

WEAR, R. G. 1968. Life-history studies on New Zealand Brachyura. 3. Family Ocypodidae. First stage zoea larva of Hemiplax hirtipes (Jacquinot, 1853). N. Z. J. mar. freshw. Res. 2:698-707.

WILLEMS, K. A. 1982. Larval development of the land crab Gecarcinus lateralis lateralis (Fréminville, 1835) (Brachyura: Gecarcinidae) reared in the laboratory. J. Crust. Biol. 2 (2):180-201. 